\title{
EKSEKUSI PUTUSAN PENGADILAN AGAMA TERKAIT NAFKAH IDDAH, MUT'AH
}

\author{
Muhammad Ridwan \\ Magister Hukum Universitas Semarang
}

\begin{abstract}
ABSTRAK
Penelitian ini bertujuan untuk menganalisa eksekusi putusan pengadilan agama mengenai nafkah Iddah, Mut'ah. Perceraian merupakan suatu perbuatan hukum yang tentunya akan membawa pula akibat-akibat hukum tertentu. Perceraian dapat terjadi karena adanya talak dari suami atau gugatan perceraian yang dilakukan oleh istri, Pengadilan dapat mewajibkan kepada mantan suami untuk memberikan biaya penghidupan dan atau menentukan sesuatu kewajiban kepada mantan istrinya. Kewajiban dari mantan suami yang berupa mut'ah, nafkah iddah (bila istrinya tidak nusyus) dan nafkah untuk anak-anak. Pelaksanaan eksekusi terkait dengan kewajiban memberikan nafkah bagi bekas suami sebelum ikrar talak tidak diatur dalam undang undang, namun prakteknya hakim selalu berusaha agar bekas suami melaksanakan kewajibannya yaitu memberi nafkah untuk bekas istri sebelum dibacakan ikrar talak. Penelitian ini adalah penelitian yuridis normative. Hasil penelitian menunjukkan bahwa pelaksanaan eksekusi isi putusan terkait nafkah yang telah mempunyai kekuatan hukum tetap Hakim Pengadilan Agama Semarang selalu mengantisipasi dengan cara hakim meajibkan bagi bekas suami untuk memberikan nafkah iddah, mut'ah kepada bekas istri sebelum pengucapan ikrar talak. Dalam prakteknya eksekusi nafkah tersebut tidak bisa dilaksanakan karena tidak ada aturan hukum yang jelas yang mengatur tentang eksekusi sebelum ikrar talak.bahwa upaya yang bisa dilakukan oleh bekas istri apabila mantan suami enggan memberikan nafkah iddah, mut'ah adalah mengajukan permohonan eksekusi terkait hak hak nafkah yang seharusnya diterima melalui ketua pengadilan agama.
\end{abstract}

Kata Kunci : Bekas suami; nafkah iddah; mut'ah; pengadilan agama 


\title{
DECISION OF EXECUTION OF RELIGIOUS COURT RELATED TO IDDAH, MUT'AH
}

\author{
Muhammad Ridwan \\ Master of Law, University of Semarang
}

\begin{abstract}
This study aims to analyze the execution of religious court decisions regarding the livelihood of Iddah, Mut'ah. Divorce is a legal act which certainly will also bring certain legal consequences. Divorce can occur due to divorce from the husband or divorce lawsuit committed by the wife, the court may require the ex-husband to provide living expenses and or determine an obligation to the ex-wife. Obligations of ex-husband in the form of mut'ah, iddah income (if his wife is not nusyus) and income for children. The execution was related to the obligation to provide for the ex-husband before the divorce pledge was not regulated in the law, but in practice the judge always tried to make the ex-husband carry out his obligation to provide income for the exwife before reciting the divorce pledge. This research is a normative juridical study. The results showed that the execution of the contents of the decision related to a living that already has permanent legal force Judges of the Semarang Religious Court always anticipate by way of a judge requiring ex-husbands to provide iddah, mut'ah to their ex-wife before pronouncing divorce pledge. In practice the execution of the living cannot be carried out because there is no clear legal regulation governing the execution before the pledge of divorce. That the effort that can be done by the ex-wife if the ex-husband is reluctant to provide iddah, Mut'ah is applying for an execution related to the rights of livelihood which should have been received through the head of the religious court.
\end{abstract}

Keywords: Former husband; iddah making a living, mut'ah, religious court 


\section{A. PENDAHULUAN}

Di antara sekian masalah yang menyangkut hubungan antar manusia atau dalam perspektif Agama Islam dikenal dengan istilah muamalat duniawiyat, masalah perkawinan (munakahat) dengan segala persoalan yang berada di sekitarnya mendapatkan perhatiannya yang istimewa. ${ }^{1}$ Perkawinan merupakan peristiwa penting dalam kehidupan setiap manusia. Perkawinan yang terjadi antara seorang pria dengan seorang wanita akan menimbulkan akibat lahir maupun batin antara mereka, terhadap masyarakat dan juga hubungannya dengan harta kekayaan yang diperoleh di antara mereka baik sebelum dan selama perkawinan.

Setiap pasangan suami istri senantiasa mendambakan teciptanya rumah tangga yang sakinah, mawaddah, dan waramah. Salah satu faktor penunjang terwujudnya rumah tangga yang sesuai dengan konsep Islam ini adalah harta kekayaan yang merupakan zinatu al-hayat, baik harta yang bergerak maupun tidak, bahkan termasuk didalamnya surat-surat berharga dan hak intelektual. ${ }^{2}$

Perkawinan merupakan suatu perjanjian yang mengikat lahir batin dengan dasar iman. Hidup bersama merupakan suatu fenomena yang merupakan kodrat bagi setiap manusia, dan mengingat manusia merupakan mahluk sosial, sehingga hanya manusia manusia yang memiliki kelainan kelainan sajalah yang mampu hidup mengasingkan diri dari orang-orang lainnya. Dalam bentuknya yang terkecil, hidup bersama itu dimulai dengan adanya keluarga. Lembaga perkawinan merupakan dasar peradaban umat manusia dan tempat bagi manusia untuk mengabadikan diri satu sama lain dan saling menghormati perasaan. ${ }^{3}$

Undang-Undang No. 1 Tahun 1974 tentang Perkawinan, merupakan unifikasi dalam bidang hukum perkawinan bagi seluruh warga negara Indonesia. Undang-Undang Perkawinan tersebut diundangkan pada tangal 2 Januari 1974 dan mulai berlaku secara efektif pada tanggal 1 Oktober 1975 bersamaan dengan saat

1 Musthafa Kamal dkk, Fikh Islam, Citra Karsa Mandiri, Yogyakarta, 2002, hal. 243

2 Masrokimin, Perbandingan Antara Hukum Positif Dengan Hukum Islam Mengenai Pembagian Harta Bersama Akibat Perceraian, Jurnal Ius Constituendum Vol 1 No 1, Magister Hukum Universitas Semarang, 2016, Semarang, hlm 2.

3 Lili Rasjidi, Hukum Perkawinan dan Perceraian di Malaysia dan di Indonesia. PT. Remaja Rosdakarya. Bandung. 1991. hal. 1. 
berlakunya Peraturan Pelaksanaannya yakni PP No. 9 Tahun 1975 tentang Pelaksanaan Undang-Undang No. 1 Tahun 1974.

Dengan demikian terhadap perkawinan dan hal hal yang berkaitan dengan perkawinan apabila terjadi sebelum 1 Oktober 1975, digunakan ketentuanketentuan atau peraturan-peraturan lama. Sebagaimana diketahui, sebelum Undang-Undang Perkawinan belum efektif, di Indonesia terdapat beraneka ketentuan yang mengatur tentang perkawinan di antaranya adalah Hukum Islam, Hukum Adat, Kitab Undang-Undang Hukum Perdata (KUH Perdata), Peraturan perkawinan Bagi Golongan Indonesia Kristen (HOCI), Peraturan Perkawinan Campuran (Reglemennt Gemengde uwelijken / RGH).

Sedangkan jika perkawinan dan hal yang berkaitan dengan perkawinan itu dilakukan setelah 1 Oktober 1975, maka dasar yang digunakan adalah ketentuan Undang-Undang Perkawinan. Pasal 1 Undang-Undang Nomor 1 Tahun 1974 tentang Perkawinan merumuskan pengertian perkawinan sebagai berikut :

"Perkawinan adalah ikatan lahir batin antara seorang pria dengan seorang wanita sebagai suami istri dengan tujuan membentuk keluarga (rumah tangga) yang bahagia dan kekal berdasarkan Ketuhanan Yang Maha Esa.”

Pasal 2 ayat (1) Undang-Undang Nomor 1 Tahun 1974 tentang sahnya perkawinan yang berbunyi :

"Perkawinan adalah sah apabila dilakukan menurut hukum masing masing agamanya dan kepercayaannya itu"

Setiap pasangan suami istri mendambakan keharmonisan berumah tangga, sebagaimana tujuan dari suatu perkawinan yang telah disebutkan di atas. Prinsip perkawinan sendiri adalah untuk membentuk suatu keluarga atau rumah tangga yang tentram, damai dan kekal untuk selama lamanya, namun perjalanan kehidupan tidak selalu sesuai dengan keinginan manusia. Percerian dapat terjadi oleh berbagai faktor dalam suatu perkawinan. Perceraian merupakan realitas yang tidak dapat dihindari apabila kedua belah pihak telah mencoba untuk mencari penyelesaian dengan jalan damai yakni dengan jalan musyawarah, jika masih 
belum terdapat kesepakatan dan merasa tidak bisa melanjutkan keutuhan keluarga maka barulah kedua belah pihak bisa membawa permasalahan ini ke pengadilan untuk dicari jalan keluar yang terbaik. Pengadilan merupakan upaya terakhir untuk mempersatukan kembali suami dan istri yang berniat bercerai tadi dengan jalan membuka lagi pintu perdamaian dengan cara musyawarah memakai penengah yakni Mediator, untuk orang yang beragama Islam akan membawa permasalahan ini kepada Pengadilan Agama sementara untuk agama lainnya merujuk kepada Pengadilan Negeri tempat mereka tinggal.

Secara umum alasan perceraian dalam masyarakat adalah sudah tidak ada lagi kecocokan di antara suami dan istri yang disebabkan oleh berbagai hal. Perceraian merupakan suatu perbuatan hukum yang tentunya akan membawa pula akibat akibat hukum tertentu. Sesuai dengan ketentuan Pasal 144 Kompilasi Hukum Islam (KHI), perceraian dapat terjadi karena adanya talak dari suami atau gugatan perceraian yang dilakukan oleh istri, perceraian tersebut hanya dapat dilakukan atas dasar putusan hakim di depan sidang Pengadilan Agama (Pasal $115 \mathrm{KHI})$.

Perceraian yang terjadi karena adanya talak dari suami terhadap istrinya, maka sesuai dengan ketentuan Pasal 41 (c) Undang-Undang Nomor 1 Tahun 1974, pengadilan dapat mewajibkan kepada mantan suami untuk memberikan biaya penghidupan dan atau menentukan sesuatu kewajiban kepada bekas istrinya. Pasal ini menetukan kewajiban dari mantan suami yang berupa mut'ah, nafkah iddah (bila istrinya tidak nusyuz) dan nafkah untuk anak-anak baik berupa uang atau benda, kecuali qobla ad dhukul, memberikan nafkah, maskan (tempat tinggal dan kiswah (pakaian) kepada bekas istri selama masa iddah ( menunggu), kecuali bekas istri telah dijatuhi talak ba'in atau nusyuz, melunasi mahar yang masih terhutang seluruhnya dan separo apabila qobla ad dhukhul, memberikan biaya hadlonah untuk anak anaknya yang belum mencapai umur 21 tahun. ${ }^{4}$ dan memberikan nafkah iddahnya kepada bekas istrinya kecuali istrinya nusyuz. Bahwa bekas Suami wajib memberikan mut'ah yang layak kepada bekas istrinya.

\footnotetext{
${ }^{4}$ Pasal 49 Inpres No 1 tahun 1991 Tentang Kompilasi Hukum Islam
} 
Dalam hal ini walaupun tidak adanya suatu tuntutan dari istri majelis hakim dapat menghukum mantan suami membayar kepada mantan istri berupa mut'ah, nafkah iddah dan nafkah anak. Setiap putusan pengadilan idealnya diapatuhi dan dilaksanakan sendiri oleh Tergugat. Namun jika tidak demikian hukum acara yang berlaku memberikan jalan yang harus ditempuh oleh pihak Penggugat untuk memperoleh hak haknya yaitu melalui permohonan eksekusi. Eksekusi adalah hal menjalankan putusan pengadilan yang sudah berkekuatan hukum tetap. Pelaksanaan eksekusi Putusan Pengadilan Agama Semarang Perkara Nomor 1778/Pdt.G/2016 terkait dengan pebayaran nafkah nafkah kepada bekas istri adalah dengan cara mewajibkan bekas suami untuk membayarkan sejumlah nafkah yang telah diputuskan oleh majelis pemerikas perkara tersebut sebelum bekas suami mengucapkan ikrar talak didepan majelis hakim, namun apabila bekas suami tidak menyanggupi sejumlah nafkah yang telah ditentukan, maka majelis hakim dengan ijtihadnya akan menunda pelaksanaan ikrar tersebut dalam jangka waktu maksimal enam bulan, namun apabila bekas Isitri merelakan bekas suami membayarkan nafkah terseut setelah ikrar, maka persidangan ikrar akan dilanjutkan. Berdasarkan pasal 70 Undang undang Peradilan Agama mengatur apabila suami telah melaksanakan rangkaian persidangan dapat mengikrarkan talaknya apabila Permohonan cerai talak yang dikeluarkan majelis hakim telah berkekuatan hukum tetap. Apabila suami enggan memenuhi kewajibanya maka upaya hukum yang dapat ditempuh istrinya adalah dengan cara mengajukan permohonan eksekusi kepada Ketua Pengadilan Agama.

\section{B. PERMASALAHAN}

Berdasarkan latar belakang masalah yang telah penulis paparkan diatas, maka yang menjadi permasalahan dalam penelitian ini ini adalah sebagai berikut :

1. Bagaimana Pelaksanaan Eksekusi Putusan Pengadilan Agama Terkait Nafkah Iddah, Mut'ah dalam kajian Putusan Nomor Perkara 1778/Pdt.G/2016 Di Pengadilan Agama Semarang ? 
2. Apakah kendala dan solusi atas pelaksanaan Eksekusi Putusan Pengadilan Agama Terkait Nafkah Iddah, Mut'ah dalam kajian Putusan Nomor Perkara 1778/Pdt.G2016 Di Pengadilan Agama Semarang ?

\section{PEMBAHASAN}

\section{Tinjauan Umum Tentang Perkawinan}

\section{Pengertian Perkawinan}

Perkawinan merupakan suatu kejadian yang sangat penting dalam kehidupan seseorang. Bagi bangsa Indonesia ritual perkawinan tidak hanya dipandang sebagai peristiwa sosial keduniawian, melainkan juga dipandang sebagai peristiwa sakral. Setelah selesai ritual, timbullah ikatan perkawinan antara seorang laki-laki dan seorang wanita yang menimbulkan akibat dalam berbagai bidang, meliputi hubungan lahiriah dan spiritual di antara mereka (suami-isteri) itu sendiri secara pribadi dankemasyarakatan, serta hubungan antara mereka dengan harta kekayaan yang diperoleh sebelum selama, dan sesudah perkawinan.

Pasal 1 Undang-Undang Nomor 1 Tahun 1974 tentang perkawinan menjelaskan bahwa Perkawinan ialah ikatan lahir batin antara seorang pria dewasa dengan seorang wanita sebagai suami istri dengan tujuan membentuk keluarga (rumah tangga) yang bahagia dan kekal berdasarkan Ketuhanan Yang Maha Esa. Menurut Undang-Undang Perkawinan barulah ada perkawinan apabila dilakukan antara seorang pria dan seorang wanita, berarti perkawinan sama dengan perikatan. ${ }^{5}$ Tentulah tidak dinamakan perkawinan apabila yang terikat dalam perjanjian itu 2 (dua) orang pria saja ataupun 2 (dua) orang wanita saja. Demikian juga tidaklah merupakan perkawinan bila dilakukan antara banyak pria dan banyak wanita. Tentulah juga mungkin tidak merupakan perkawinan kalau sekiranya ikatan lahir batin itu tidak bahagia, atau perkawinan itu tidak kekal dan tidak berdasarkan Ketuhanan Yang Maha Esa

\section{Akibat Hukum dari Perkawinan yang Sah}

\footnotetext{
${ }^{5}$ Hilman Hadikusumo, Hukum Perkawinan Indonesia, Mandar Maju, Bandung, 1990, hal. 7
} 
Perkawinan dalam aspek relegius maupun kehidupan sosial kemasyarakatan merupakan peristiwa yang sakral, namun dalam apabila kita tinjau dari aspek hukumnya perkawinan bukan hanya suatu peristiwa yang sakral saja akan tetapi juga merupakan suatu peristiwa hukum yangmemiliki akibat-akibat hukum tertentu.

Perkawinan yang sah menurut hukum akan menimbulkan akibat hukum sebagai berikut :

1. Timbulnya hubungan antara suami-istri

2. Timbulnya harta benda dalam perkawinan

3. Timbulnyan hubungan antara orang tua dan anak. ${ }^{6}$

Akibat perkawinan terhadap suami isteri menimbulkan hak dan kewajiban antara suami isteri. Lebih lanjut Pasal 30 sampai dengan Pasal 34 Undang-Undang Nomor 1 Tahun 1974 tentang Perkawinan mengatur hak dan kewajiban antara suami isteri, sebagai suatu konsekuensi dari perkawinan, yaitu sebagai berikut :

1. Suami isteri memikul kewajiban yang luhur untuk menegakkan rumah tangga yang menjadi sendi dasar susunan masyarakat;

2. Hak dan kedudukan isteri adalah seimbang dengan hak dan kedudukan suami dalam kehidupan rumah tangga dan dalam pergaulan masyarakat;

3. Suami-isteri berhak melakukan perbuatan hukum;

4. Suami adalah kepala rumah tangga dan isteri ibu rumah tangga. Disamping itu suami wajib memberikan segala sesuatu keperluan hidup berumah tangga dengan kemampuannya dan isteri wajib mengatur rumah tangga sebaikbaiknya;

5. Suami isteri wajib saling mencintai, hormat menghormati, setia dan memberi bantuan lahir batin satu kepada yang lain;

6. Suami isteri harus mempunyai tempat kediaman yang tetap dan tempat kediaman tesebut ditentukan oleh suami isteri bersama.

\footnotetext{
${ }^{6}$ Mulyadi, Hukum Perkawinan Indonesia, Badan Penerbit Universitas Diponegoro Semarang, 2008, hal. 41
} 
Selanjutnya apabila suami atau isteri melalaikan kewajiban, maka masing-masing dapat mengajukan gugatan kepada Pengadilan. Sedangkan akibat perkawinan yang menyangkut harta benda dalam perkawinan, diatur alam Pasal 35 sampai Pasal 37 UU No. 1 Tahun 1974, yang menetapkan sebagai berikut :

Harta benda yang diperoleh selama perkawinan menjadi harta bersama, sedangkan harta bawaan dari masing-masing suami atau isteri dan harta benda yang diperoleh masing-masing sebagai hadiah atau warisan, adalah di bawah penguasaan masing-masing, sepanjang tidak ditentukan lain oleh suami-isteri. Apabila ditentukan oleh suami isteri, maka harta bawaan suami isteri tersebut menjadi harta bersama. Untuk menentukan agar harta bawaan suami dan isteri menjadi harta bersama, maka suami dan isteri tersebut harus membuat perjanjian kawin. Perjanjian kawin harus dibuat secara tertulis dan disahkan oleh Pegawai Pencatat Perkawinan sebelum atau pada saat perkawinan dilangsungkan;

Perjanjian kawin adalah perjanjian perjanjian yang dibuat calon suami dan isteri untuk mengatur akibat-akibat perkawinannya terhadap harta kekayaan mereka. ${ }^{7}$ Perjanjian kawin diatur dalam Pasal 29 UU No. 1 Tahun 1974, yang menetapkan :

a. Pada waktu atau sebelum perkawinan dilangsungkan, kedua pihak atas persetujuan bersama dapat mengadakan perjanjian kawin yang disahkan oleh Pegawai Pencatat Perkawinan, setelah mana isinya berlaku juga terhadap pihak ketiga sepanjang pihak ketiga tersangkut. Perjanjian tersebut tidak dapat disahkan bilamana melanggar batas-batas hukum agama dan kesusilaan.

b. Perjanjian tersebut berlaku sejak perkawinan dilangsungkan

c. Selama perkawinan berlangsung perjanjian tersebut tidak dapat dirubah, kecuali bila dari kedua belah pihak ada persetujuan untuk merubah dan Perubahan tidak merugikan pihak ketiga.

1. Mengenai harta bersama, suami atau isteri dapat bertindak bertindak atas persetujuan kedua belah pihak. Sedangkan mengenai harta bawaan masing-

7 Ko Tjay Sing, Hukum Perdata Jilid I Hukum Keluarga (Diktat Lengkap), Fakultas hukum Universitas Diponegoro, Semarang, 1981, hal. 217. 
masing, suami isteri mempunyai hak sepenuhnya untuk melakukan perbuatan hukum hak sepenuhnya untuk melakukan perbuatan hukum mengenai harta bendanya. Adapun hak suami dan isteri untuk mempergunakan atau memakai harta bersama dengan persetujuan kedua belah pihak secara timbal balik, menurut Riduan Syahrani adalah sewajarnya, mengingat hak dan kedudukan suami dalam kehidupan rumah tangga dan pergaulan hidup bersama dalam masyarakat, dimana masing-masing pihak berhak melakukan perbuatan hukum. $^{8}$

2. Bila perkawinan putus karena perceraian, harta bersama diatur menurut hukumnya masing-masing. Menurut penjelasan Pasal 37 UU No. 1 tahun 1974, yaitu hukum agama (kaidah agama), hukum adat dan hukum-hukum lainnya.

\section{Tinjauan Umum tentang Perceraian}

Perceraian dalam istilah ahli fiqih disebut "talak" atau "furqah" Adapun arti daripada talak ialah membuka ikatan membatalkan perjanjian, sedangkan furqah artinya bercerai. Kedua kata itu dipakai oleh para ahli fiqih sebagai satu istilah yang berarti bercerai antara suami isteri. Menurut istilah Hukum Islam, talak dapat berarti :

a. Menghilangkan ikatan perkawinan atau rnengurangi keterikatannya dengan menggunakan ucapan tertentu.

b. Melepaskan ikatan perkawinan dan mengakhiri hubungan suami isteri.

c. Melepaskan ikatan perkawinan dengan ucapan talak atau yang sepadan dengan itu. ${ }^{9}$ Meskipun Islam mensyariatkan perceraian tetapi bukan berarti Islam menyukai terjadinya perceraian dari suatu perkawinan.

Pelaksanaan perceraian itu harus berdasarkan pada suatu alasan yang kuat, karena ini merupakan jalan terakhir yang ditempuh oleh suami istri, apabila cara-cara lain

8 Erwin Prahara, Pertimbangan Hakim Terhadap Tanggung Jawab Tergugat Dakam Pembereian Nafkah Pasca Putusan Cerai, JURNAL USM Law Review Vol 1 No 1, Magister Hukum Universitas Semarang, Semarang, hlm 2.

9 Zuhri Hamid, Pokok-pokok Hukum Perkawinan Islam dan Undang-Undang Perkawinan di Indonesia, Bina Cipta, Yogyakarta, 1978, hlm. 73. 
yang telah diusahakan sebelumnya tetap tidak dapat mengembalikan keutuhan hidup rumah tangga suami isteri tersebut.

Suatu perkawinan dapat putus dikarenakan beberapa sebab berikut :

a. Kematian salah satu pihak

b. Perceraian baik atas tuntuta suami maupun istri

c. Karena putusan pengadilan.

Dalam hal ini perceraian dilihat sebagai akhir dari suatu ketidakstabilan perkawinan dimana pasangan suami istri kemudian hidup terpisah dan secara resmi diakui oleh hukum yang berlaku. Putusanya perkawinan karena perceraian dalam Pasal 199 KUH Perdata dapat terjadi karena dua hal, yaitu talak dan gugat cerai. Talak adalah ikrar suami dihadapan Pengadilan Agama yang menjadi salah satu sebab putusnya perkawinan. ${ }^{10}$ Perceraian hanya dapat dilakukan di depan sidang pengadilan setelah pengadilan yang bersangkutan berusaha dan tidak berhasil mendamaikan kedua belah pihak. Sehubungan dengan adanya ketentuan bahwa perceraian itu harus dilakukan di depan pengadilan, maka ketentuan ini berlaku juga bagi mereka yang beragama Islam. Walapun pada dasarnya Hukum Islam tidak menentukan, bahwa perceraian itu harus dilakukan di depan pengadilan. Namun oleh karena ketentuan ini lebih banyak mendatangkan kebaikan maka sudah sepantasnya apabila orang Islam wajib mengikuti ketentuan ini. $^{11}$

\section{Tata Cara Perceraian}

Tata cara perceraian di depan sidang pengadilan diatur dalam Peraturan Pemerintah Nomor 9 Tahun 1975, gugatan perceraian diajukan kepada pengadilan, sedangkan tata cara mengajukan gugatan diatur dengan Pasal 14 dan 38 Peraturan Pemerintah Nomor 9 tahun 1975, yang bunyinya sebagai berikut :

Seorang suami yang telah melangsungkan perkawinan menurut Agama Islam, yang akan menceraikan istrinya, mengajukan surat kepada pengadilan ditempat

10 Zuhri Hamid, Pokok-pokok Hukum Perkawinan Islam dan Undang-Undang Perkawinan di Indonesia, Bina Cipta, Yogyakarta, 1978, hal. 73.

11 Soemijati, Hukum Perkawinan Islam dan Undang-Undang Perkawinan, Liberty, Yogyakarta, 1986, hal. 126 
tinggalnya yang sesuai pemberitahuan bahwa ia bermaksud menceraikan istrinya dengan alasan-alasan serta meminta kepada pengadilan agar diadakan sidang untuk keperluan itu.

Perkawinan serta sahnya perceraian hanya dapat dibuktikan dengan keputusan pengadilan Agama untuk orang-orang Islam dan Pengadilan Negeri untuk orangorang non Islam. Akibat dari putusnya perkawinan karena perceraian baik bagi pihak suami maupun istri tetap berkewajiban memelihara dan mendidik anak anaknya semata-mata demi kepentingan anak.

\section{Nafkah Iddah dan Mut'ah dalam Hukum Positif di Indonesia}

\section{a. Nafkah Iddah}

Nafkah Iddah adalah salah satu kewajiban yang timbul ketika terjadi perceraian karena talak. Dalam UU Perkawinan No. 1 Tahun 1974 ayat (c) dijelaskan bahwa ketika terjadi perceraian maka pengadilan dapat mewajibkan kepada suami untuk memberikan biaya penghidupan dan / atau menentukan suatu kewajiban bagi bekas istri.

Oleh karena itu untuk menjamin adanya kepastian hukum, keadilan serta kemanfaatan hukum maka secara lebih rinci dalam KHI dijelaskan dalam Pasal 149 bahwa apabila perkawinan putus karena talak maka bekas suami dapat diwajibkan beberapa hal. Dalam poin b disebutkan salah satu kewajiban suami tersebut adalah "untuk memberi nafkah, maskan dan kiswah kepada bekas istri selama dalam iddah kecuali bekas istri telah dijatuhi talak ba'in atau nusyuz dan dalam keadaan tidak hamil“ .

Dari potongan pasal ini dapat difahami bahwa bekas suami berkewajiban untuk memberikan sejumlah nafkah kepada bekas istrnya selama dalam masa iddah. Permohonan untuk meminta hak berupa nafkah iddah tersebut dalam dilakukan bersama sama permohonan ikrar talak dan bisa juga ketika ikrar talak telah dilakukan, sebagaimana hal ini dijelaskan dalam UU No 7 Tahun 1989 Pasal 66 ayat 5. 
Mengenai ukuran nafkah iddah dalam peraturan di Indonesia tidak ditemukan secara pasti, namun dalam PP No. 9 Tahun 1975 dan UU Peradilan Agama No. 7 Tahun 1989 dijelaskan bahwa selama berlangsungnya gugatan perceraian berdasarkan permohonan Pemohon ataupun Termohon, Pengadilan dapat menentukan jumlah nafkah yang harus ditanggung oleh suami

\section{b. Nafkah Mut'ah}

Ketenuan Mut'ah ini telah diatur dalam hukum positif yang ada di Indonesia sebagaimana dalam Pasal 41 (c) UU No. 1 Tahun 1974. Dalam pasal tersebut dijelaskan bahwa suami dapat dibebankan suatu kewajiban setelah perceraian. Mengenai kewajiban tersebut dijelaskan lebih rinci dalam KHI pada pasal 149 KHI dijelaskan mengenai kewajiban kewajiban yang dapat dibebankan kepada mantan suami. Pada poin (a) dijelaskan bahwa ketika terjadi perceraian karena talak mantan suami berkewajiban untuk memberikan mut'ah yang layak kepada bekas istrinya, baik berupa uang atau benda, kecuali bekas istri tersebut qobla dukhul.

Dalam KHI dijelaskan Pasal 158 bahwa suami menjadi wajib memberikan mut'ah jika :

a. Belum ditetapkan mahar bagi istri ba'da dukhul

b. Perceraian atas kehendak suami

Berdasarkan Pasal 158 ayat (b) ini, jika perceraian tersebut berasal dari kehendak istri yaitu dengan jalan khulu' maka suami tidak wajib untuk membayarkan mut'ah kepada bekas istrinya. Suami berkewajiban memberikan mut'ah apabila syarat yang terdapat dala KHI pasal 158 tersebut ada. Apabila tidak terdapat ketentuan yang disebut dala Pasal 158 KHI ini, maka suami tidak wajib untuk memberikan mut'ah kepada bekas istrinya.

III.Pelaksanaan Eksekusi Putusan Pengadilan Agama terkait Nafkah Iddah, Mut'ah dalam Kajian putusan Nomor Perkara 1778/Pdt.G/2016 Di Pengadilan Agama Semarang 
Pada dasarnya setiap orang yang melaksanakan perkawinan mempunyai tujuan atau cita-cita untuk selama-lamanya. Tetapi adakalanya suatu perkawinan karena sebab-sebab tertentu dapat berakibat putus atau tidak dapat dilanjutkan lagi, dan pada akhirnya perkawinan tersebut harus berakhir dengan perceraian antara suami istri. Undang-Undang Nomor 1 Tahun 1974 tentang Perkawinan menyebut secara umum mengenai putusnya hubungan perkawinan dalam tiga golongan seperti yang tercantum dalam Pasal 38 Undang-Undang Nomor 1 Tahun 1974 tentang Perkawinan sebagai berikut.

\section{a. Kematian}

Putusnya perkawinan sebab kematian adalah dengan meninggalnya salah salah satu pihak (suami atau istri). Sejak saat meninggalnya salah satu pihak itulah perkawinan itu menjadi putus.

b. Perceraian

Putusnya perkawinan karena perceraian adalah dengan pernyataan talak dari seorang suami.

c. Atas keputusan pengadilan.

Putusnya perkawinan atas putusan pengadilan adalah putusnya perkawinan karena gugatan istri. Gugatan seorang istri yang melangsungkan perkawinan menurut agama Islam diajukan ke Pengadilan Agama, sedangkan gugatan seorang suami/istri yang melangsungkan perkawinan menurut agama dan kepercayaan bukan Islam gugatan diajukan ke Pengadilan Negeri.

Dalam Undang-Undang Nomor 1 Tahun 1974 tentang Perkawinan, dicantumkanlah suatu asas bahwa tujuan perkawinan adalah untuk membentuk keluarga bahagia, kekal dan sejahtera, dengan demikian perceraian bukanlah suatu hal yang mudah untuk dilakukan menurut undang-undang ini. Untuk melakukan perceraian harus ada cukup alasan, bahwa antara suami istri itu tidak akan dapat hidup rukun sebagai suami istri. Perceraian hanya mungkin dengan salah satu alasan seperti disebutkan dalam Undang-Undang Perkawinan dan Peraturan Pelaksanaannya, yang harus dilakukan didepan Pengadilan. Bagi 
warganegara yang beragama Islam perceraian dilakukan di depan Pengadilan Agama. Suatu perceraian secara hukum hanya dapat dilakukan dipengadilan karena pengadilan merupakan forum hukum yang dapat memberikan keputusan bagi para pihak terkait. Mengenai tata cara Perceraian, peraturan perundangundangan yang berlaku di Indonesia membagi dua klasifikasi cara berdasarkan agama atau kepercayaan yang dipeluk oleh pemohon Perceraian yaitu:

1. Tata cara perceraian bagi mereka yang melangsungkan perkawinan yang beragama Islam berdasarkan Pasal 14 sampai dengan Pasal 18 Peraturan Pemerintah Nomor 9 Tahun 1975 tentang Pelaksanaan Undang-Undang Nomor 1 Tahun 1974 tentang Perkawinan, serta Pasal 28 dan 29 Peraturan Menteri Agama Republik Indonesia Nomor 3 Tahun 1975. Pada kedua peraturan tersebut pada pokoknya adalah sebagai berikut:

a. Gugatan perceraian yang diajukan oleh suami atau istri diajukan kepada pengadilan yang daerah hukumnya meliputi tempat kediaman tergugat. Permohonan ini harus dilengkapi dengan alasan-alasannya dan, meminta untuk diadakan siding keperluan tersebut. Pengadilan Agama akan mempelajari isisurat permohonan dan dalam waktu selambat-lambatnya tiga puluh hari setelah diterimanya permohonan, pemohon akan dipanggil bersama-sama dengan istrinya untuk didengar dan diminta penjelasan tentang segala sesuatu yang berkenaan dengan maksudnya untuk bercerai.

b. Setelah menerima penjelasan, Pengadilan Agama untuk pertama kalinya berusaha mendamaikan kembali kedua belah pihak yang akan bercerai dengan meminta bantuan Badan Penasehat Perkawinan dan Penyelesaian Perceraian yang biasa dikenal dengan BP4.

c. Dalam persidangan tentunya diwarnai dengan ketegangan ketegangan dari kedua pihak yang menginginkan dilaksanakan perceraian, sehingga sidang tidak harus selesai sekali bersidang tetapi mungkin juga berkalikali. Pada setiap kali persidangan hakim juga berusaha mendamaikan 
lagi, sampai pengadilan berpendapat bahwa kedua pihak tidak dapat lagi didamaikan dan sudah cukup alasan talak. Lalu diadakan lagi sidang untuk mendengarkan dan menyaksikan pengucapan talak, di mana pada saat tersebut dihadiri juga oleh istrinya atau wakilnya. Sehabis mengikrarkan talak bekas suami kemudian menandatangani surat ikrar.

d. Selanjutnya Pengadilan membuat surat keterangan tentang terjadinya talak rangkap empat untuk keperluan: lembar pertama dilampiri surat ikrar dikirimkan kepada Pegawai Pencatat Nikah setempat Lembar kedua dan ketiga masing masing diberikan kepada suami istri sedang lembar keempat untuk arsip.

e. Perceraian terjadi pada saat pengucapan talak di depan sidang Pengadilan Agama tersebut di atas.

Apabila talak sudah terjadi, maka kutipan akta nikah yang dipegang oleh masing-masing suami dan istri dicabut dan ditahan oleh Pengadilan Agama di tempat talak itu diikrarkan dan diberi catatan pada kolom yang tersedia bahwa pemilik sudah menjatuhkan/dijatuhi talak. ${ }^{12}$

2. Tata-cara bagi seorang suami atau istri yang melangsungkan perkawinan menurut agama dan kepercayaan selain Islam. Gugatan perceraian dengan alasan-alasan seperti yang sudah dikemukakan sebelumnya, dan diajukan baik oleh suami ataupun istri atau wakil kepada Pengadilan Negeri dengan daerah hukum yang meliputi wilayah tempat tinggal tergugat. Apabila ada hal-hal lain di luar itu, misalnya tempat tergugat tidak menentu, permohonan perceraian ditujukan kepada Pengadilan Negeri dengan wilayah hukumnya meliputi tempat tunggal si penggugat. Gugatan cerai karena ditinggal terus menerus tanpa alasan yang sah dapat diajukan pada Pengadilan Negeri dimana penggugat berdomisili, asal sudah melewati batas waktu yang diisyaratkan dalam Undang-Undang Perkawinan. Sedangkan gugatan cerai dengan alasan

\footnotetext{
${ }^{12}$ Hoerudin, Ahrurn, Pengadilan Agama (Bahasan tentang Pengertian,Pengajuan Perkara dan Kewenangan Pengadilan Agama Setelah Berlakunya UU No. 7 Tahun 1989 tentang Peradilan Agama), Citra Aditya Bakti, Bandung, 1999, hal. 26
} 
cekcok yang tidak ada harapan untuk rukunkembali, diajukan di Pengadilan Negeri tempat kediaman tergugat.

Adapun mengenai pemeriksaan perceraian yang ditentukan dalambUndang-Undang terdiri dari:

\section{Cerai Talak}

a. Suami mempunyai jalur tertentu dalam upaya menuntut upaya perceraian yaitu jalur suami melalui cerai talak.

b. Jalur hukum untuk suami ditempuh melalui gugat permohonan baik lisan atau tertulis ke Pengadilan Agama.

c. Dalam UU No. 7 Tahun 1989 ditentukan sifat gugat cerai talak adalah berupa permohonan yang identik dengan gugat volunter, namun dia berbeda dengan dari gugat volunter yang murni. Gugat volunter yang mumi adalah sepihak, hanya pemohon saja. Orang yang disebut dalam permohonan sebagai objek, tidak berdiri sebagai subjek. Sedangkan dalam cerai talak istri sebagai pihak dan subjek perdata, malahan mempunyai hak untuk mengajukan banding dan kasasi. Jadi disini terlihat keunikan gugat cerai talak dibanding dengan gugat volunteer pada umumnya.

d. Suami sebagai pihak pemohon dan istri sebagai pihak termohon. Permohonan cerai talak diajukan kepada Pengadilan yang daerah hukumnya meliputi tempat kediaman termohon, kecuali apabila termohon dengan sengaja meninggalkan tempat kediaman yang ditentukan bersama tanpa ijin pemohon.

e. Dalam hal pemohon dan termohon bertempat tinggal dl luar negeri, maka permohonan diajukan kepada Pengadilan yang daerah hukumnya meliputi tempat mereka melangsungkan perkawinan

f. Pengadilan Agama dapat mengabulkan atau menolak permohonan tersebut dan terhadap keputusan tersebut dapat diminta upaya banding dan kasasi.

g. Pengadilan Agama yang bersangkutan mempelajari permohonan tersebut dalam waktu tiga puluh hari setelah itu memanggil pemohon dan termohon untuk 
dimintai penjelasan segala sesuatu yang berhubungan dengan maksud menjatuhkan talak.

h. Setelah Pengadilan Agama tidak berhasil menasehati atau mendamaikan kedua belah pihak dan ternyata cukup alasan untuk menjatuhkan talak serta yang bersangkutan tidak mungkin lagi hidup rukun dalam rumah tangga, Pengadilan Agama menjatuhkan keputusannya tentang ijin untuk mengikrarkan talak.

i. Setelah keputusan mempunyai keputusan hukum tetap, suami mengikrarkan talak di depan sidang Pengadilan Agama, dihadiri oleh istri atau kuasanya

j. Bila suami tidak mengucapkan ikrar talak dalam waktu tempo enam bulan terhitung sejak keputusan Pengadilan Agama tentang ijin ikrar talak baginya mempunyai kekuatan hukum tetap, maka hak suami untuk diadakan mengikrarkan talak gugur dan ikatan perkawinan tetap utuh.

k. Setelah penyaksian ikrar talak, Pengadilan Agama membuat penetapan tentang terjadinya talak rangkap empat yang merupakan bukti perceraian bagi bekas suami atau istri.

1. Helai pertama beserta surat ikrar talak dikirimkan kepadaPegawai pencatat nikah yang mewilayahi tempat tinggal suami untuk diadakan pencatatan helai kedua dan ketiga masing-masing diberikan kepada suami istri dan helai keempat disimpan oleh Pengadilan Agama.

\section{Cerai Gugat.}

a. Jalur untuk menuntut perceraian bagi istri adalah cerai gugat, yang pada dasarnya tata cara pemeriksaan tidak banyak berbeda dengan cerai talak. Misal persamaannya tentang hal yang berkenaan dengan pengiriman salinan dan pemberian akta cerai.

b. Yang bertindak sebagai penggugat adalah istri dan di tempat lain suami sebagai tergugat.

c. Gugatan diajukan kepada Pengadilan Agama meliputi tempat kediaman penggugat. 
d. Seorang istri yang mengajukan gugatan perceraian dengan jalan khuluk, menyampaikan pemohonan kepada Pengadilan Agama yang mewilayahi tempat tinggalnya disertai alasan alasannya.

e. Dalam sidang tersebut Pengadilan Agama memberikan penjelasan tentang akibat khuluk dan memberikan nasehat nasehatnya.

f. Setelah itu kedua belah pihak menyepakati besarnya iwald atau tebusan.

g. Jika sudah menyepakati besarnya iwald maka Pengadilan Agama memberikan penetapan tentang ijin bagi suami untuk mengikrarkan talaknya di depan sidang Pengadilan Agama. Hukum Acara yang berlaku di pengadilan dalam perkara perceraian, secara garis besar mengikuti Hukum Acara Perdata. Namun terdapat kekhususan yang berlaku di dalam Hukum Acara di Pengadilan Agama, meliputi kewenangan relatif Pengadilan Agama, sifat persidangan, pemanggilan, pemeriksaan, pembuktian, dan biaya perkara, serta pelaksanaan putusan. Kekhususan Hukum Acara yang berlaku pada Pengadilan Agama di dasarkan pada Pasal 54 Undang-Undang Nomor 7 Tahun 1989 tentang Peradilan Agama jo Undang-Undang Nomor 3 Tahun 2006 tentang Perubahan Atas UndangUndang Nomor 7 Tahun 1989 tentang Peradilan Agama (Undang-Undang Peradilan Agama). Dengan demikian Hukum Acara yang berlaku pada Pengadilan Agama adalah Hukum Acara Perdata yang berlaku pada Pengadilan Umum, kecuali mengenai sejumlah hal lainnnya, yang diatur khusus, meliputi:

a. Bentuk dan proses perkara;

b. Kewenangan relatif Pengadilan Agama;

c. Pemanggilan pihak-pihak;

d. Pemeriksaan, pembuktian dan upaya damai;

e. Biaya Perkara;

f. Putusan hakim dan upaya hukum.

Selain mengacu kepada Undang-Undang Peradilan Agama, menurut penulis proses beracara di Pengadilan Agama juga mengacu pada UndangUndang Nomor 1 Tahun 1974 tentang Perkawinan jo Peraturan Pemerintah 
Nomor 9 Tahun 1975 tentang Pelaksanaan Undang-Undang Nomor 1 Tahun 1974 tentang Perkawinan Undang-Undang Nomor 5 Tahun 2004 tentang Mahkamah Agung. Kemudian Peraturan Menteri Agama Nomor 2 Tahun 1987 tentang Wali Hakim dan Kompilasi Hukum Islam (KHI), yang dengan Instruksi Presiden Republik Indonesia Nomor 1 Tahun 1991 jo Keputusan Menteri Agama Nomor 154 Tahun 1991. Seluruh Undang-Undang dan peraturan tersebut dapat dipergunakan dalam menyelesaikan masalah-masalah atau perkara dibidang perkawinan, kewarisan, wasiat hibah, shodaqoh berdasarkan Hukum Islam serta Kitab-kitab Fiqih Islam, sebagai sumber penemuan hukum.

\section{Solusi atas Pelaksanaan Eksekusi Putusan Pengadilan Agama terkait Nafkah} Iddah, Mut'ah dalam kajian putusan Nomor Perkara 1778/Pdt.G/2016 Di Pengadilan Agama Semarang.

Bahwa dalam rangka memenuhi asas keadilan dan kemanfaatan bagi para pihak pencari keadilan, maka putusan majelis hakim yang telah mempunyai kekuatan hukum tetap ( inkracht van gewijsde) terhadap perkara Cerai Talak Perkara Nomor 1778/Pdt.G/2016/PA.Smg yang isi putusannya adalah sebagai berikut :

\section{MENGADILI}

Dalam Konvensi

1. Mengabulkan permohonan Pemohon

2. Menetapkan memberi izin Pemohon (wawan Dwi Fitriyanto Bin Abdul Kodir) untuk menjatuhkan Talak Satu Roj'i terhadap Termohon (Ida Fitriyah Binti Nardi)

3. Memerintahkan Panitera Pengadilan Agama Semarang mengirimkan salinan Penetapan Ikrar Talak kepada Pegawai Pencatat Nikah Kantor Urusan Agama Kecamatan Pegandon Kabupaten Kendal guna dicatat dalam daftar yang disediakan itu

Dalam Rekonvensi

1. Mengabulkan Gugatan Rekonvensi untuk sebagian ; 
2. Menetapkan anak yang bernama : Afika Nabila Maulida berada dibawah asuhan Penggugat Rekonvensi ;

3. Menetapkan hak Penggugat akibat perceraian berupa :

3.1 kekurangan nafkah madliyah/lampau Rp. 500.000,-x15 bulan $=$ Rp. 7.500.000,- (tujuh juta lima ratus ribu rupiah)

3.2 Nafkah Iddah selama 3 bulan sejumlah Rp. 1.500.000,- (satu juta lima ratus ribu rupiah);

3.3 Mut'ah berupa uang sejumlah Rp. 5.000.000,- (lima juta rupiah);

4. Menetapkan nafkah anak Penggugat Rekonvensi dan Tergugat Rekonvensi yang bernama Afika Nabila Maulida sebesar Rp. 600.000,(enam ratus ribu rupiah) diluar biaya pendidikan dan kesehatan setiap bulanya sampai anak tersebut dewasa dan dapat berdiri sendiri dengan penambahan $10 \%$ setiap tahunnya ;

5. Menghukum Tergugat Rekonvensi untuk membayar hak hak Penggugat Rekonvensi dan nafkah anak sebagaimana tersebut pada point 3 dan point 4 amar putusan ini secara sukarela. Apabila dikemudian hari Tergugat Rekonvensi enggan melaksanakan kewajibannya itu, maka akan dilakukan eksekusi menurut hukum ;

6. Menolak untuk selain dan selebihnya ;

Bahwa putusan tersebut harus dilaksanakan dengan cara dilakukan eksekusi terlebih dahulu terkait dengan sejumlah nafkah nafkah yang wajib dibayarkan oleh bekas suami meskipun ada upaya hukum berupa banding, Kasasi maupun Peninjauan Kembali (PK) baik bekas suami mengucapkan ikrar talak atau tidak dengan dibuatkan payung hukum yakni undang undang, Peraturan peraturan, Surat Edaran dari Mahkamah Agung Republik Indonesia, sehingga dengan adanya Undang undang atau Peraturan peraturan yang bisa dijadikan alas / dasar hukum Majelis Hakim untuk mengeksekusi putusan tersebut. Dengan demikian kepastian hukum, kedailan hukum, dan kemanfaatan hukum benar benar dirasakan oleh bekas istri. 


\section{E. PENUTUP}

Pelaksanaan Eksekusi Putusan Pengadilan Agama Terkait Nafkah Iddah, Mut'ah dalam kajian Putusan Nomor Perkara 1778/Pdt.G/2016/PA.Smg di Pengadilan Agama Semarang yakni Hakim yang mengadili perkara tersebut menghimbau kepada Suami untuk meberikan kewajiban nafkah yang harus diberikan kepada istri sebelum Suami mengucapkan Ikrar Talak di depan Majelis Hakim yang memutus dan mengadili perkara tersebut, namun dalam hal ini Suami enggan melaksanakan isi putusan tersebut karena suami merasa tidak mampu dengan jumlah nafkah Iddah, Mut'ah kepada bekas Istri sebagaimna yang telah diputus oleh Hakim pemerikasa perkara tersebut, kemudian Majelis Hakim menunda pelaksanaan pengucapan Ikrar takak tersebut dengan batas maksimal sesuai dalam pasal 70 ayat (6) Undang Undang Peradilan Agama Nomor 50 Tahun 2009 yang menyatakan “ Jika Suami dalam tenggang waktu 6 (enam) bulan sejak ditetapkannya hari sidang penyaksian Ikrar Talak, tidak datang menghadap sendiri atau tidak mengirim wakilnya meskipun telah mendapat panggilan secara sah atau patut maka gugurlah kekuatan penetapan tersebut, dan perceraian tidak dapat diajukan lagi berdasarkan alasan yang sama”. Bahwa yang menjadi kendala pelaksanaan eksekusi Putusan Pengadilan terkait Nafkah Iddah dan Mut'ah dalam kajian Putusan Nomor Perkara 1778/Pdt.G/2016/PA.Smg adalah Suami tidak mau melaksanakan isi Putusan tersebut karena dinilai Putusan tersebut tidak mencerminkan keadilan yang mana suami dengan kondisi riil tidak mampu tetapi putusan nafkah terkait Iddah dan Mut'ah terlalu tinggi bagi suami, dengan demikian istri tidak mendapatkan hak haknya yakni menerima nafkah Iddah dan Mut'ah dari Suami. Bahwa dengan adanya kendala tersebut perlu adanya solusi dalam permasalahan ini yakni harus dilakukan eksekusi terlebih dahulu terkait sejumlah nafkah nafkah yang harus dibayarkan oleh Suami meskipun ada upaya hukum berupa Banding, Kasasi maupun Peninjauan Kembali baik Suami mengucapkan Ikrar Talak atau tidak dengan dibuatkan aturan yang jelas berupa Undang undang, atau Peraturan peraturan, Surat Edaran dari Mahkamah Agung Republik Indonesia, 
sehingga dengan adanya Undang undang atau Peraturan peraturan yang bisa dijadikan dasar hukum Majelis Hakim untuk mengeksekusi putusan tersebut.

\section{DAFTAR PUSTAKA}

\section{BUKU}

Ahrurn, Hoerudin. 1999. Pengadilan Agama (Bahasan tentang Pengertian, Pengajuan Perkara dan Kewenangan Pengadilan Agama Setelah Berlakunya UU No. 7 Tahun 1989 tentangPeradilan Agama), Citra Aditya Bakti, Bandung.

Anselmus Strauss dan Juliat Corbin, Basic of Qualitative, Research, Grounded Theory Procedural and Tecnique, Newbury, Park London, New Delhi

Bisri, Cik Hasan. 2000. Peradilan Agama di Indonesia. PT Raja Grafindo, Jakarta.

Budiono, Abdul Rachmad. 2003. Peradilan Agama dan Hukum Islam di Indonesia, Bayumedia, Malang.

Djai's Mochammad dan Koosmargono, RMJ. 2008. Membaca dan Mengerti HIR, Semarang, Badan Penerbit Universitas Diponegoro.

HR. Otje Salman S dan Anton F Susanto, Teori Hukum, Bandung : Refika Aditama Hadikusumo, Hilman. 1990. Hukum Perkawinan Indonesia. Mandar Maju, Bandung.

Halim, Abdul. 2000. Peradilan Agama Dalam Politik Hukum di Indonesia, dari Otorter Konservatif Menuju Konfigurasi Demokratis-Responsif, PT Raja Grafindo, Jakarta.

Hamid, Zuhri. 1978. Pokok-pokok Hukum Perkawinan Islam dan Undang-Undang Perkawinan di Indonesia. Bina Cipta. Yogyakarta.

Harahap, M. Yahya. 1988. Ruang Lingkup Permasalahan Eksekusi Bidang Perdata, PT. Gramedia, Jakarta.

Hasan, KN. Sofyan. 1994. Dasar-dasar Memahami Hukum Islam diIndonesia, Usaha Nasional, Surabaya.

Kamal, Musthafa dkk. 2002. Fikh Islam. Citra Karsa Mandiri.Yogyakarta.82 Marwan Mas, Pengantar Ilmu Hukum, Jakarta : Ghalia Indonesia

Mertokusumo, Sudikno. 1995, Hukum Acara Perdata Indonesia, Liberty, Yogyakarta.

Mulyadi, 2008. Hukum Perkawinan Indonesia, Badan Penerbit Universitas Diponegoro, Semarang.

Panduan Penulisan Usulan Penelitian dan Tesis, Semarang : Program Studi Magister Ilmu Hukum, Program Pasca Sarjana Universitas Semarang, 2015.

Ramulyo, Muhammad Idris, 1999. Hukum Perkawinan Islam, Bumi Aksara, Jakarta. . 2000. Hukum Perkawinan Hukum Kewarisan, Hukum Acara Peradilan Agama dan Zakat Menurut Hukum Islam. Sinar Grafika, Jakarta. 
Rasjidi, Lili. 1991. Hukum Perkawinan dan Perceraian di Malaysia dan di Indonesia. PT. Remaja Rosdakarya. Bandung.

Soekanto, Soerjono, Pengantar Penelitian Hukum. UI-Press, Jakarta.

Soerjono Soekanto, dan Sri Mamudji. 1990. Penelitian Hukum Normatif Suatu Tinjauan Singkat, PT. Radja Grafindo Persada, Jakarta.

Soemijati, 1986. Hukum Perkawinan Islam dan Undang-Undang Perkawinan. Liberty. Yogakarta.

Subekti, R. dan Tjitrosudibio, R. 1990. KUHPerdata, Pradnya, Jakarta.

Sudarsono, 1994. Hukum Perkawinan Nasional, Jakarta: Rineka Cipta.

Susilo, Budi. 2008. Prosedur Gugatan Cerai, Pustaka Yustisia, Yogyakarta.

Sutantio, Retnowulan dan Oeripkartawinata, Iskandar. 1990, Hukum Acara Perdata dalam Teori dan Praktek, C V. Mandar Madju, Bandung.

Syahrani, Riduan. 1985. Seluk Beluk dan Asas-asas Hukum Perdata, Alumni, Bandung.

Susilowati Irianto \& Shidarta, 2013, Metode Penelitian Hukum Konstelasi dan Refleksi, Yayasan Pustaka Obor Indonesia, 2013, Jakarta.

Sudikno Mertokusumo, 2009, Penemuan Hukum Sebuah Pengantar, Liberty, Yogyakarta.

Sudarsono, 2007, Kamus Hukum Edisi Baru, Cetakan Kelima, Rineka Cipta, Jakarta.

Sri Mamudji, 2005, Metode Penelitian dan Penulisan Hukum, Badan Penerbit Fakultas Hukum Indonesia, 2005, Jakarta.

Waluyo, Bambang. 1991. Penelitian Hukum DalaM Praktek, Sinar Grafika, Jakarta.

\section{JURNAL}

Erwin Prahara, Pertimbangan Hakim Terhadap Tanggung Jawab Tergugat Dakam Pembereian Nafkah Pasca Putusan Cerai, JURNAL USM Law Review Vol 1 No 1, Magister Hukum Universitas Semarang, Semarang.

Masrokimin, Perbandingan Antara Hukum Positif Dengan Hukum Islam Mengenai Pembagian Harta Bersama Akibat Perceraian, Jurnal Ius Constituendum Vol 1 No 1, Magister Hukum Universitas Semarang, 2016, Semarang. http://dx.doi.org/10.26623/jic.v1i2.548

\section{UNDANG-UNDANG}

Undang - undang Dasar 1945

Kitab Undang- Undang Hukum Perdata

Undang-undang Nomor 1 Tahun 1974 Tentang Perkawinan

Undang-undang Nomor 50 Tahun 2009 Tentang Peradilan Agama

Undang-undang Nomor 48 Tahun 2009 Tentang Kekuasaan Kehakiman

Peraturan Pemerintah Nomor 10 Tahun 1975 Tentang Pelaksanaan Undang-undang Nomor 1 Tahun 1974

Kompilasi Hukum Islam (KHI) 